\title{
PEMBERDAYAAN MASYARAKAT MELALUI PELATIHAN PEMBUATAN
} PUPUK KOMPOS

\section{COMMUNITY EMPOWERMENT THROUGH COMPOSTING TRAINING}

\author{
${ }^{1)}$ Arum Asriyanti Suhastyo \\ ${ }^{2}$ Program Studi Agroteknologi \\ Politeknik Banjarnegara \\ Jl. Raya Madukara Km. 2 Kenteng Banjarnegara, Jawa Tengah \\ Telepon: (0286)591145 \\ email: arumasriyanti11@gmail.com
}

\begin{abstract}
ABSTRAK
Kegiatan pemberdayaan masyarakat berupa transfer teknologi tentang pembuatan kompos adalah sebagai upaya memanfaatkan potensi lingkungan sekitar berupa sisa sampah organik. Kegiatan ini dilaksanakan di Kelurahan Rejasa Kecamatan Madukara Kabupaten Banjarnegara. Metode yang digunakan dalam kegiatan ini yaitu pemberian materi dan demonstrasi. Pemberian materi tentang berbagai bahan sisa sampah organik disekitar lingkungan Kelurahah Rejasa yang dapat digunakan sebagai sumber bahan baku pembuatan pupuk kompos. Demonstrasi dilakukan dengan melakukan praktik pembuatan pupuk kompos dengan menggunakan bahan baku hijauan/dedaunan, bonggol pisang, dan kotoran sapi yang banyak terdapat disekitar Kelurahan Rejasa, kemudian ditambahkan dengan super decomposer, sekam padi, gula pasir, dan air. Transfer teknologi pembuatan pupuk kompos memberikan manfaat yang besar yaitu adanya peningkatan pengetahuan warga tentang manfaat bahan sisa sampah organik sebagi bahan baku pembuatan pupuk kompos.
\end{abstract}

Kata kunci: pemberdayaan, pupuk, organik, kompos

\section{ABSTRACT}

Community development and transfer of technology on composting is an effort to exploit the potential of the surrounding environment in the form of residual organic waste. This event was held in the village Rejasa Madukara District of Banjarnegara district. The method used in this activity is the provision of material and demonstrations. Provision of material on a variety of materials leftover organic waste village Rejasa surrounding environment that can be used as a source of raw material for making compost. Demonstrations conducted by practicing composting using forage raw material / foliage, banana weevil, and cow dung that is widely available around the village Rejasa, then added with a super decomposer, rice husks, sugar, and water. Transfer composting technology provides great benefits that their increased knowledge of citizens about the benefits of waste materials of organic waste as a raw material for making compost.

Key Word:empowerment, fertilizers, organic, compost

Submited : 30 Nopember 2016 Revision : 2 Desember 2016 Accepted : 21 Januari 2017

\section{PENDAHULUAN}

Kelurahan Rejasa merupakan salah satu dari 12 kelurahan di Kabupaten Banjarnegara. Secara geografis Kelurahan Rejasa masih dekat dengan ibukota kabupaten kurang lebih berjarak $2 \mathrm{~km}$, dengan letak di sebelah utara kabupaten.. Kelurahan Rejasa mempunyai luas wilayah $106.850 \mathrm{Ha}$ dan secara administrasi dibagi menjadi 4 RW, 14 RT. Jumlah penduduk Kelurahan Rejasa sebanyak 2.342 jiwa dengan jumlah laki-laki 1111 jiwa dan 


\section{Arum Asriyanti Suhastyo \\ Pemberdayaan Masyarakat Melalui Pelatihan \\ Pembuatan Pupuk Kompos di Kelurahan Rejasa Banajrnegara}

jumlah perempuan 1231 jiwa. Mata pencaharian penduduk Kelurahan Rejasa beragam dari pegawai negeri, pegawai swasta, petani, peternak, pedagang serta ibu rumah tangga (Banjarnegarakab, 2016).

Kelurahan Rejasa mempunyai potensi untuk memanfaatkan lahan pekarangan sebagai salah satu sumber mencapai kemandirian masyarakat dengan budidaya tanaman organik. Budidaya tanaman organik yang akan dilakukan berbasis sumberdaya lokal dengan memanfaatkan potensi lingkungan sekitar. Penggunaan pupuk juga dengan memanfaatkan sampah organik, seresah daun tanaman sekitar serta sisa peternakan seperti kotoran sapi yang banyak terdapat di Kelurahan Rejasa. Pemanfaatan sisa bahan organik yang dibuat pupuk kompos salah satunya sangat bermanfaat untuk mengurangi pencemaran lingkungan. Penggunaan pupuk kompos dalam jangka panjang dapat memperbaiki sifat fisik, kimia dan biologi tanah. Pupuk kompos mudah dibuat dan teknologinya sederhana. Kompos adalah bahan-bahan organik (sampah organik) yang telahmengalami proses pelapukan karena adanya interaksi antara mikroorganisme(bakteri pembusuk) yang bekerja di dalamnya. Bahan-bahan organik tersebutseperti daun, rumput, jerami, sisasisa ranting dan dahan, kotoran hewan,rerontokan kembang, air kencing, dan lain-lain (Murbandono, 2000).

Selama ini sisa tanaman dan kotoran hewan belum sepenuhnya dimanfaatkan sebagai pengganti pupuk buatan. Kompos bisa terjadi dengan sendirinya, lewat proses alamiah. Namun,proses tersebut berlangsung lama sekali, dapat mencapai puluhan tahun. Bahan-bahanorganik tidak dapat langsung digunakan tanpa dikomposkan terlebih dahulukarena bahan organik yang masih mentah tidak dapat langsung dimanfaatkan olehtanaman. Bahan organik itu harus diuraikan terlebih dahulu agar tanaman dapatmenyerap unsur hara yang dikandungnya. Menurut Prihandini dan Purwanto (2007) proses pengomposan adalah proses menurunkan $\mathrm{C} / \mathrm{N}$ bahan organik hingga sama dengan $\mathrm{C} / \mathrm{N}$ tanah $(<$ 20).

Menurut Setyorini et al (2006), agar pembuatan kompos berhasil maka syarat yang diperlukan antara lain:

1. Ukuran bahan mentah. Sampai batas tertentu, semakin kecil ukuran potongan bahan mentahnya, semakin cepat pula waktu pembusukannya. Ukuran bahan sekitar 5-10 cm sesuai untuk pengomposan ditinjau dari aspek sirkulasi udara yang mungkin terjadi.

2. Suhu dan ketinggian bahan. Makin tinggi volume timbunan makin mudah timbunan menjadi panas, sebaliknya apabila terlalu dangkal akan kehilangan panas dengan cepat. Dalam keadaan suhu kurang optimum, bakteri-bakteri yang bekerja pada timbunan tersebut tidak akan berkembang secara wajar, akibatnya pembuatan kompos akan berlangsung lebih lama, Sebaliknya timbunan terlalu tinggi akan mengakibatkan suhu menjadi tinggi.

3. Nisbah $\mathrm{C} / \mathrm{N}$. Mikroba perombak bahan organik memerlukan karbon sebagai sumber energi untuk pertumbuhan dan nitrogen untuk pembentukan protein. Rasio C/N 30 merupakan nilai yang diperlukan untuk proses pengomposan yang efisien. Apabila $\mathrm{C} / \mathrm{N}$ rasio terlalu besar $(>40)$ atau terlalu kecil $(<20)$ akan mengganggu kegiatan biologis proses dekomposisi.

4. Kelembaban. Timbunan kompos harus selalu lembab, dengan kandungan lengas $50-60 \%$ agar mikroba tetap beraktivitas. Kelebihan air akan mengakibatkan volume udara jadi berkurang, sebaliknya bila terlalu kering proses dekomposisi akan terhenti.

5. Aerasi. Aktivitas mikroba aerob memerlukan oksigen selama proses perombakan berlangsung. Pembalikan timbunan bahan kompos selama proses 


\section{Arum Asriyanti Suhastyo \\ Pemberdayaan Masyarakat Melalui Pelatihan \\ Pembuatan Pupuk Kompos di Kelurahan Rejasa Banajrnegara}

dekomposisi berlangsung sangat dibutuhkan dan berguna untuk mengatur pasokan oksigen bagi aktivitas mikroba.

6. Nilai pH. pH optimum berkisar 5,58,0 . Pada pH tinggi terjadi kehilangan nitrogen akibat volatilisasi. Pada awal pengomposan umumny $\mathrm{pH}$ agak masam karena aktivitas bakteri menghasilkan asam. Namun selanjutnya $\mathrm{pH}$ akan bergerak menuju netral.

7.

Selama ini masyarakat belum terlalu paham dengan manfaat kompos. Padahal kompos mempunyai manfaat diantaranya adalah: 1) memperbaiki struktur tanah berlempung sehingga menjadi ringan; 2) memperbesar daya ikat tanah berpasir sehingga tanah tidak berderai; 3) menambah daya ikat tanah terhadap air dan unsur-unsur hara tanah; 4) memperbaiki drainase dan tata udara dalam tanah; 5) mengandung unsur hara yang lengkap, walaupun jumlahnya sedikit (jumlah ini tergantung dari bahan pembuat pupuk organik); 6) membantu proses pelapukan bahan mineral; 7) memberi ketersediaan bahan makanan bagi mikrobia; serta 8) menurunkan aktivitas mikroorganisme yang merugikan (Yovita, 2001).

Bahan untuk pembuatan kompos sangat mudah diperoleh karena tersedia disekitar kita, dan cara pembuatannya pun sangat mudah semua orang bisa membuat baik dalam skala besar maupun untuk keperluan pekarangan rumah sendiri. Akan tetapi masih kurangnya pengetahuan dan keterampilan tentang pembuatan pupuk kompos berbahan sumber daya lokal, membuat masyarakat enggan untuk membuatnya, maka dari itu perlu adanya pelatihan pembuatan pupuk kompos.

\section{METODE}

Kegiatan ini dilaksanakan pada tanggal 27 Januari 2016 di Balai Pertemuan Kelurahan Rejasa, Kecamatan Madukara, Kabupaten Banjarnegara. Peserta kegiatan yaitu warga Rt 2 Rw 2 Kelurahan Rejasa. Metode yang digunakan dalam kegiatan transfer teknologi ini yaitu pemberian materi dan demonstrasi. Peserta menyimak paparan dari pemateri yang dilanjutkan dengan demonstrasi pembuatan kompos. Alat-alat yang digunakan dalam pelatihan berupa hijauan/daun-daunan/bonggol pisang, kotoran sapi, super decomposer, sekam padi, gula pasir, air, terpal, golok/pisau, ember dan cangkul.

\section{HASIL DAN PEMBAHASAN}

Kegiatan pemberdayaan masyarakat berupa transfer teknologi tentang pembuatan kompos adalah sebagai upaya memanfaatkan potensi lingkungan sekitar berupa sisa sampah organik. Warga Rt 2 Rw 2 Kelurahan Rejasa yang mengikuti kegiatan ini memperoleh pengetahuan tentang pembuatan pupuk kompos.

Pada pembuatan kompos ini digunakan limbah bahan organik yang ada disekitar lingkungan RT $2 \mathrm{Rw} 2$, seperti hijaun/dedaunan, bonggol pisang, kotoran sapi. Metode pengomposan yang dilakukan yaitu secara aerob dipermukaan tanah. Menurut Simanungkalit et al (2009) terdapat beberapa metode pengomposan antara lain:

1. Metode Indore.Pengomposan dilakukan di dalam lubang, yang dibuat dekat kandang ternak. Lubang berukuran kedalaman $1 \mathrm{~m}$, lebar 1,5-2 m, panjang lubang tergantung dari ketersediaan bahan. Bahan dasar yang digunakan adalah campuran sisa/residu tanaman, kotoran ternak, urine ternak, abu bakaran kayu, dan air. Bahan yang keras tidak 


\section{Arum Asriyanti Suhastyo \\ Pemberdayaan Masyarakat Melalui Pelatihan \\ Pembuatan Pupuk Kompos di Kelurahan Rejasa Banajrnegara}

boleh melebihi 10\%. Semua bahan yang tersedia disusun menurut lapisan-lapisan dengan ketebalan masing-masing $15 \mathrm{~cm}$, dengan total ketebalan 1,0-1,5 m. Setiap lapisan disiram urine ternak secara merata, kelembaban tumpukan dijaga sekitar 90\%. Pembalikan dilakukan 3 kali, yaitu pada 15, 30 dan 60 hari setelah kompos mulai dibuat. Metode ini juda disebut metode anaerob.

2. Metode heap. Pengomposan dilakukan di permukaan tanah. Petak timbunan dibuat berukuran lebar $2 \mathrm{~m}$, panjang $2 \mathrm{~m}$ dan tinggi timbunan 1,5 m. Lapisan dasar pertama adalah bahan yang kaya karbon setebal $15 \mathrm{~cm}$ (dedaunan, jerami, serbuk gergaji, dan batang jagung), lapisan berikutnya adalah bahan yang kaya nitrogen setebal 10-15 cm (residu sisa tanaman, rumput segar, kotoran ternak, dan sampah organik). Timbunan disusun hingga ketinggian 1,5 $\mathrm{m}$. Kelembaban dijaga dengan menambahkan air secukupnya. Pembalikan dilakukan setelah 6 dan 12 minggu setelah proses pengomposan berlangsung.

3. Metode Berkeley. Bahan dasar yang digunakan adalah: dua bagian bahan organik kaya selulosa dan satu bagian bahan organik kaya nitrogen dengan nilai rasio $\mathrm{C} / \mathrm{N}$ 30:1. Bahan disusun berlapis-lapis hingga ketebalan berukuran 2,4 x 2,2 x 1,5 m. Setelah 2-3 hari proses pengomposan berjalan terbentuk suhu tinggi, secara berkala kompos harus dibalik. Setelah hari ke10, suhu mulai menurun dan bahan berubah menjadi remah dan berwarna coklat gelap. Pengomposan selesai setelah 2 minggu.

Selain bahan utama sebagai bahan dasar pembuatan kompos diperlukan bahan lain seperti dekomposer/aktivator, sekam padi/serbuk gergaji, gula pasir, serta
air.Kompos bisa dibuat secara alamiah namun proses ini memerlukan waktu yang lama, karena mikroorganisme pengurainya sedikit, oleh karena itu ditambahkan dekomposer untuk mempercepat proses pengomposan. Dekomposer akan mempengaruhi pembuatan kompos dengan dua cara yaitu inokulasi strain mikroorganisme yang efektif dalam menghancurkan bahan organik dan meningkatkan kadar nitrogen yang merupakan makanan tambahan bagi mikroorganisme tersebut (Gaur, 1983). Dekomposer kompos bisa dibuat sendiri dengan memanfaatkan sumber daya alam/bahan -bahan organik yang ada disekitar kita seperti bonggol pisang, daun gamal, rebung, sisa buah-buahan dan lainlaian. Bahan-bahan ini mengandung mikroorganisme sehingga disebut juga MOL ( mikroorganisme lokal). Akan tetapi sekarang sudah banyak dijual di kios-kios pertanian dekomposer yang mengandung berbagai bakteri pengurai yang bisa sesuai dengan bahan dasar pembuatan kompos.

Pada pembuatan kompos ini juga ditambahkan sekam padi. Sekam padi berfungsi sangat baik untuk meningkatkan kualitas kompos dari segi teksturnya selain untuk mengurangi kelebihan air. Selain itu juga ditambahkan gula pasir yang berfungsi untuk sumber energi bagi mikroorganisme pengurai selama proses pembuatan kompos. Air juga dibutuhkan kehidupan mikroorganisme didalam dekompser kompos .

Langkah selanjutnya dalam proses pembuatan kompos ini adalah bahan-bahan yang besar dipotong-potong atau dicincang dengan ukuran 2-4 cm. Pada pemotongan bahan tidak boleh terlau besar karena mengakibatkan proses penguraian berjalan lambat sedangkan kalau terlalu kecil akan menyebabkan terurainya/hilangnya difusi oksigen sehingga akan terjadi aktivitas bakteri anaerob. Bentuk bahan berpengaruh terhadap kelancaran difusi oksigen yang 


\section{Arum Asriyanti Suhastyo \\ Pemberdayaan Masyarakat Melalui Pelatihan \\ Pembuatan Pupuk Kompos di Kelurahan Rejasa Banajrnegara}

diperlukan serta karbondioksida yang dihasilkan ( Suriawiria, 2002). Selanjutnya bahan baku disusun berlapis, lapisan dasar yang pertama adalah kotoran sapi kemudian berturut-turut potongan daun-daunan, bonggol pisang sekam padi, setelah itu siram dengan air gula dan dekomposer bergantian sedikit-sedikit sampai lembab.

Kelembaban yang dibutuhkan adalah sekitar 50-60\% agar mikroba tetap beraktivitas. Kelembaban yang lebih rendah atau lebih tinggi akan menyebabkan mikroorganisme tidak berkembang atau mati. Selanjutnya dibuat lapisan lagi seperti lapisan pertama dan seterusnya sampai ketinggian maksimal 1,5 m. Setelah Proses pengomposan juga sangat dipengaruhi aerasi. Aerasi yang cukup akan memperlancar proses pengomposan. Jika aerasi terlalu tinggi maka penguapan air dan kehilangan panas meningkat, sehingga memperlambat proses penguraian bahan organik. Sedangkan jika aerasi tidak cukup maka proses penguraian lambat ( Winarni, 1997).
Kompos ini dibolak-balik 2 hari sekali untuk mengontrol suhu agar tidak terlalu panas. Jika terlalu kering bisa ditambahkan air gula dan dekomposer apabila terlalu basah bisa ditambahkan sekam padi/serbuk gergaji. Setelah itu ditutup dengan terpal dan diletakkan ditempat yang teduh.

Penggunaan hijauan/dedaunan, bonggol pisang dan kotoran sapi sebagai bahan pembuatan kompos merupakan pemanfaatan potensi lokal. Disekitar Rt 2 $\mathrm{Rw} 2$ banyak terdapat sisa kotoran sapi yang belum termanfaatkan. Pengolahan kotoran sapi yang mempunyai kandungan $\mathrm{N}, \mathrm{P}$ dan $\mathrm{K}$ yang tinggi sebagai pupuk kompos dapat mensuplai unsur hara yang butuhkan tanah dan memperbaiki struktur tanah menjadi lebih baik (Setiawan, 2002). Dibawah ini adalah gambar kegiatan transfer teknologi beruapa pemaparan materi dan pembuatan kompos di Kelurahan Rejasa.

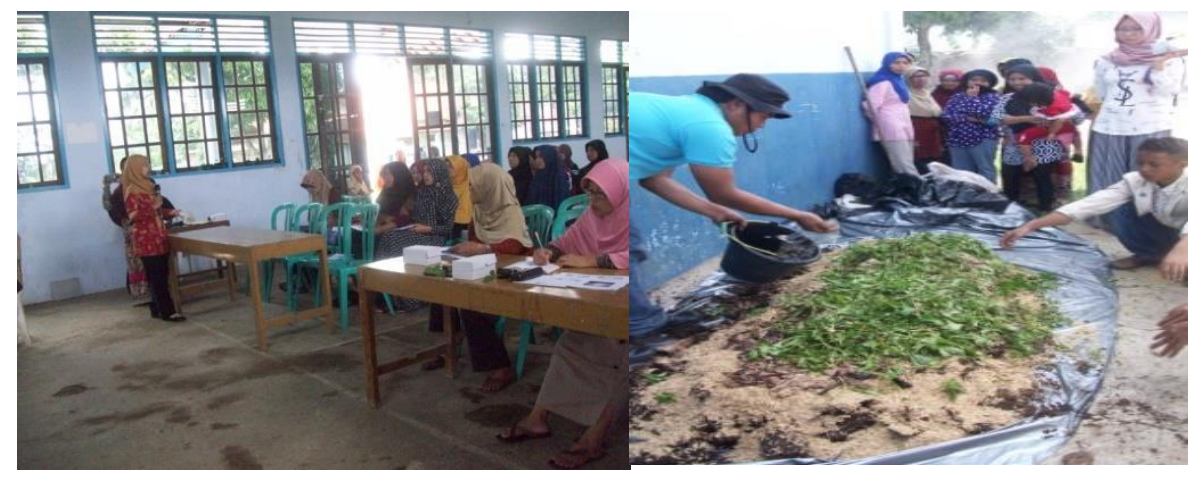

Gambar 1. Pemaparan materi dan praktek pembuatan kompos

Pupuk kompos sangat berperan dalam peningkatan produksi pertanian baik secara kualitas maupun kuantitas, mengurangi pencemaran lingkungan, dan meningkatkan kualitas lahan secara berkelanjutan. Kompos banyak mengandung mikroorganisme, dengan ditambahkannya kompos ke dalam tanah akan memacu perkembangan mikroorganisme dalam tanah, gas $\mathrm{CO}_{2}$ yang dihasilkan mikroorganisme akan dipergunakan untuk fotosintesis tanaman dan menghasilkan hormon-hormon pertumbuhan Matenggomena, 2013). 
Transfer teknologi pembuatan pupuk kompos memberikan manfaat yang besar bagi warga Rt $2 \mathrm{Rw} 2$ Kelurahan Rejasa yaitu adanya peningkatan pengetahuan tentang manfaat bahan sisa sampah organik sebagi bahan baku pembuatan pupuk kompos. Sehingga diharapkan kedepannya warga Rt 2 Rw 2 Kelurahan Rejasa bisa membuat sendiri pupuk kompos dari bahan-bahan organik yang ada disekitar mereka. Hal ini juga dalam rangka untuk mencapai kemandirian masyarakat untuk memanfaatkan potensi yang ada disekitar sebagai bahan baku pupuk organik untuk mendukung mewujudkan ketahanan pangan antara lain melalui pemanfaatan pekarangan dengan tanaman sayuran.

\section{SIMPULAN}

Warga Rt 2 Rw 2 Kelurahan Rejasa memiliki peningkatan pengetahuan dan keterampilan tentang manfaat bahan sisa sampah organik sebagi bahan baku pembuatan pupuk kompos

\section{DAFTAR PUSTAKA}

Banjarnegarakab. (2016). Kabupaten Banjarnegara.

Http://www.banjarnegarakab.go.id/. Diakses tanggal 11 Maret 2016.

Gaur, AC. (1983). A Manual of Rural Composting FAO. Rome : United Nation.

Matenggomena MF. (2013). Pemanfaatan sampah rumah tangga untuk budidaya tanaman sayuran organik di pekarangan rumah. Agroinovasi, 17 -23, XLIII, ( 3503).

Murbandono, L. HS. (2000). Membuat Kompos. Jakarta : Penebar swadaya.

Prihandini, PW, dan Purwanto, T. (2007). Petunjuk teknis pembuatan kompos berbahan kotoran sapi. Pusat Penelitian dan Pengembangan Peternakan.

Setyorini D., Saraswati R.,Anwar EA. (2006). Kompos. Pupuk Organik dan Pupuk Hayati. Editor: RDM Simanungkalit., Didi Ardi Suridikarta., Rasti Saraswati, Diah Setyorini dan Wiwik Hartatik. Balai Besar Litbang Sumberdaya Lahan Pertanian Badan Penelitian dan Pengembangan Pertanian

Setiawan, A.I. (2002). Memanfaatkan Kotoran Ternak. Cetakan ke tiga, Jakarta : Penebar Swadaya.

Simanungkalit RDM., Suriadikarta D A., Saraswati R., Setyorini D., dan Hartatik W. (2009). Teknik pembuatan kompos. Informasi Ringkas Bank Pengetahuan Padi Indonesia

Suriwiria HU., (2002). Pupuk Organik Kompos dari Sampah. Bioteknologi Agroindustri.Bandung: Humaniora Utama Press.

Winarni I. (1997). Kajian penggunaan plastik lembarandan anyaman bamboo sebagai penutup tumpukan pada pengomposan sampah kota model Cina. Skripsi. Jurusan Teknologi Industri Pertanian. Fakultas Teknologi Pertanian IPB.

Yovita. 2001. Membuat Kompos Secara Kilat. Jakarta : Penebar Swadaya. 